\title{
Method of sandwich panel calculation with discreet joints
}

\author{
Marlena Rajczyk ${ }^{1}$
}

\section{ABSTRACT:}

The article presents a method for strength calculations for a sandwich panel with ribs. The developed method of calculating sandwich panels with ribs takes into account local disturbances of the stress field in the vicinity of various design properties. The calculation method is based on the use of generalized functions, it allows the determination of the state of stresses and deformations, as well as stiffness and stability of multilayer plates.

\section{KEYWORDS:}

sandwich panel; discreet joint; calculation method

\section{Introduction}

In recent years, the quality requirements for prefabricated sandwich modular elements used in housing, industrial and public utility construction have increased.

The sandwich panel constructions have a number of advantageous features, including; being lightweight, having satisfactory stiffness, durability, and allowing for quick and effective assembly with the use of machines with long reach. Walls and panel layer joints have a flexibility that plays a positive role in building construction in areas with high seismic activity, and this structural element ensures the building's stability under dynamic loads. This is due to the fact that during energy shocks, the vibrations are absorbed by the nodes of elastic-viscous joints. It is possible to adjust the seismic resistance of the structure, adapting it to the nature of the expected load.

Another advantage of multi-layer structures is - the low weight of the structure, which allows them to be used in the construction of buildings on the so-called weak soils, as it does not determine the need to build massive foundations.

In the process of developing and improving the proposed design solution for the elements of the axial support plate structure, the issues related to the technology of their production were analyzed, including the rational arrangement of the reinforcing ribs, and optimization of the plate weight in terms of minimizing the costs of their production. The consequence of the analysis of the conditions of their production technology was the development of static and dynamic methods of strength calculations for the new structure.

\section{The technology of manufacturing sandwich panels}

Assumption, the board consists of two load-bearing and facade layers or two load-bearing layers. The technological process of the production of sandwich panels assumes gluing to the bottom plate of basalt fiber ribs between a rigid ribbed filling, between the bottom and top

1 Czestochowa University of Technology, Faculty of Civil Engineering, ul. Akademicka 3, 42-218 Częstochowa, e-mail: marlena.rajczyk@pcz.pl, orcid id: 0000-0002-4893-0931 
layer, edge ribs are also glued. In this case, the design solutions cause temperature stresses arising during the operation of the element, which disappear with time due to the rheological properties of the material - basalt fiber.

Local stresses arise in a small area of various concentrators, e.g. in ribs and corners. Due to variable loads, these stresses pose a threat both to individual elements and to the supporting structure as a whole, since the relaxation process does not ensure stress reduction to a safe level due to variable external influences.

\section{Method of strength calculations for prefabricated sandwich panels}

The proposed method of calculating a sandwich panel with ribbed filling takes into account local disturbances of the stress field in the vicinity of various design properties [1-3]. In the calculations, the system is considered as complex, consisting of two ribbed plates connected to each other at the levels of mutually occurring ribs. The state of stress of each plate with edges parallel to the OY axis (Fig. 1) is described by two equations [1]:

$$
\begin{gathered}
D \Delta^{2} W=P-\sum_{j=1}^{N}\left[E_{j} I_{j} \frac{\partial^{4} w}{\partial y^{4}}+E_{j} S_{j} \frac{1}{E h} \frac{\partial^{2}}{\partial y^{2}}\left(\frac{\partial^{2} F}{\partial x^{2}}-\mu \frac{\partial^{2} F}{\partial y^{2}}\right)\right]+M_{j} \delta\left(x-x_{i}\right) \\
\Delta^{2} F=\sum_{j=1}^{N}\left[\frac{E_{j} F_{j}}{E h}\left(\frac{\partial^{2} F}{\partial x^{2}}-\mu \frac{\partial^{2} F}{\partial y^{2}}\right)+S_{j} \frac{\partial^{2} w}{\partial y^{2}}\right]+t_{j} \delta^{\prime \prime}\left(x-x_{i}\right)
\end{gathered}
$$

where: $F_{j}, I_{j}, S_{j}$ - the area, moment of inertia, and static moment of the $j$-th edge with respect to the plate mid-plane respectively; $E_{j}, E$ - modulus of elasticity of rib and plate; $\delta\left(x-x_{i}\right)-$ delta function; P - external load; $\mathrm{D}=\frac{\mathrm{Eh}}{12\left(1-\mu^{2}\right)}$ - cylindrical stiffness; $\mathrm{m}, \mathrm{t}-$ load components transferred to the edges of the plate, upper or lower, during their mutual deformation.

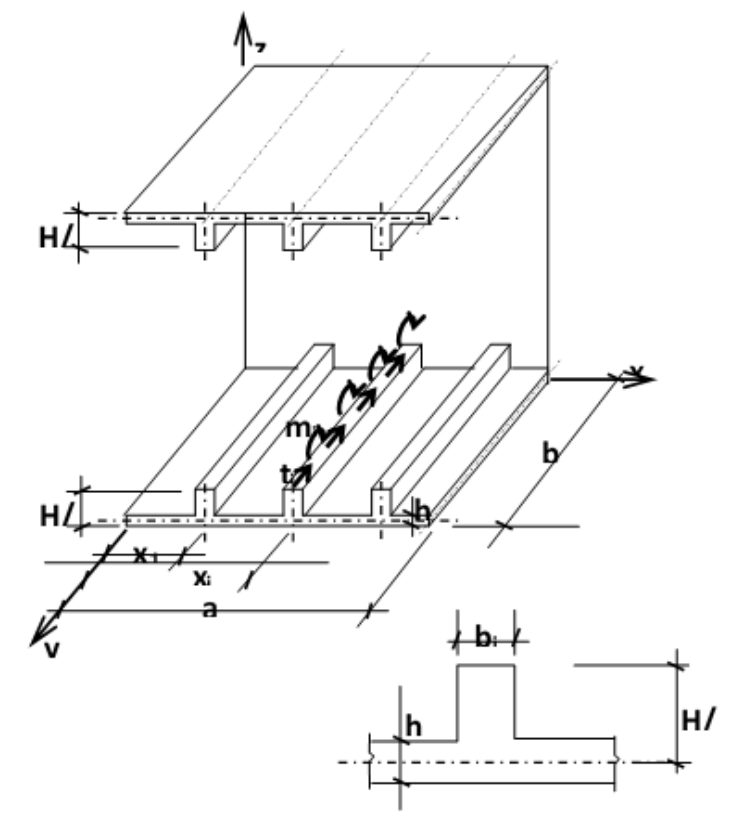

Fig. 1. Schematic for the calculation of a sandwich panel with a discrete filling in the form of ribs $[4,7]$ 
Presentation of the functions $\omega$ and $\mathrm{F}$ as an extension in the $\mathrm{y}$ coordinate:

$$
\begin{gathered}
\mathrm{w}=\sum \mathrm{w}_{\mathrm{k}} \sin \beta_{\mathrm{k}} \mathrm{y} \\
\mathrm{F}=\sum \mathrm{F}_{\mathrm{k}} \sin \beta_{\mathrm{k}} \mathrm{y}
\end{gathered}
$$

System (1) is brought to ordinary differential equations:

$$
\begin{gathered}
\mathrm{D}\left(\frac{\mathrm{d}^{2}}{\mathrm{dx}}-\beta_{\mathrm{k}}^{2}\right)^{2} \mathrm{w}_{\mathrm{k}}=\mathrm{P}-\sum \mathrm{E}_{\mathrm{i}}\left[\mathrm{I}_{\mathrm{i}} \beta_{\mathrm{k}}^{4} \mathrm{w}_{\mathrm{k}}-\mathrm{S}_{\mathrm{i}} \frac{1}{\mathrm{Eh}} \beta_{\mathrm{k}}{ }^{2}\left(\mathrm{~F}_{\mathrm{k}}^{\prime \prime}-\mu \beta_{\mathrm{k}}^{2} \mathrm{~F}_{\mathrm{k}}\right)+\mathrm{m}_{\mathrm{k}}\right] \delta\left(\mathrm{x}-\mathrm{x}_{\mathrm{i}}\right) \\
\left(\frac{d^{2}}{d x}-\beta_{k}^{2}\right)^{2} F_{k}=\frac{1}{E h} \sum\left\{E_{i}\left[F_{i}\left(F_{k[}^{\prime \prime}-\mu \beta_{k}^{2} F_{k}\right)-S_{i} \beta_{k}^{2}\right]+t_{k}\right\} \delta^{\prime \prime}\left(x-x_{i}\right)
\end{gathered}
$$

The solution to this circuit is:

$$
\begin{gathered}
\mathrm{w}_{\mathrm{k}}=\mathrm{w}_{\mathrm{k}}^{0}-\sum \mathrm{E}_{\mathrm{i}}\left\{\mathrm{I}_{\mathrm{i}} \beta_{\mathrm{k}}^{4} \omega\left(\mathrm{x}_{\mathrm{i}}\right)-\mathrm{S}_{\mathrm{i}} \frac{1}{\mathrm{Eh}} \beta_{\mathrm{k}}^{2}\left[\mathrm{~F}_{\mathrm{kx}}^{\prime \prime}\left(\mathrm{x}_{\mathrm{i}}\right)-\mu \beta_{\mathrm{k}}^{2} \mathrm{~F}_{\mathrm{k}}\left(\mathrm{x}_{\mathrm{i}}\right)\right]+\mathrm{m}_{\mathrm{k}}\right\} \psi_{\mathrm{ik}}\left(\mathrm{x}-\mathrm{x}_{\mathrm{i}}\right) \\
\mathrm{F}_{\mathrm{k}}=\frac{1}{\operatorname{Eh}} \sum\left\{\mathrm{F}_{\mathrm{i}}\left[\mathrm{F}_{\mathrm{i}}\left(\mathrm{F}_{\mathrm{kx}}^{\prime \prime}-\mu \beta_{\mathrm{k}}^{2} \mathrm{~F}_{\mathrm{k}}\right)-\mathrm{S}_{\mathrm{i}} \beta_{\mathrm{k}}^{2} \mathrm{w}_{\mathrm{k}}\left(\mathrm{x}_{\mathrm{i}}\right)+\mathrm{t}_{\mathrm{k}}\right]\right\} \psi_{\mathrm{ik}}^{\prime \prime}\left(\mathrm{x}-\mathrm{x}_{\mathrm{i}}\right)
\end{gathered}
$$

Functions $\psi_{\mathrm{ik}}$ and $\psi_{\mathrm{ik}}^{\prime \prime}$ are solutions of equations, respectively:

$$
\left(\frac{\mathrm{d}^{2}}{\mathrm{dx}^{2}}-\beta_{\mathrm{k}}\right)^{2} \Psi_{\mathrm{k}}=\delta\left(\mathrm{x}-\mathrm{x}_{\mathrm{i}}\right) ; \quad\left(\frac{\mathrm{d}^{2}}{\mathrm{dx}^{2}}-\beta_{\mathrm{k}}\right)^{2} \Psi_{\mathrm{k}}^{\prime \prime}=\delta^{\prime \prime}\left(\mathrm{x}-\mathrm{x}_{\mathrm{i}}\right) ;
$$

which allows the definition of the functions $\psi_{\mathrm{ik}} \mathrm{i} \psi_{\mathrm{ik}}^{\prime \prime}$ :

$$
\begin{aligned}
\Psi_{\mathrm{k}}= & \mathrm{C}_{1} \operatorname{ch} \beta_{\mathrm{k}} \mathrm{x}+\mathrm{C}_{2} \operatorname{sh} \beta_{\mathrm{k}} \mathrm{x}+\mathrm{C}_{3} \operatorname{ch} \beta_{\mathrm{k}} \mathrm{x}+\mathrm{C}_{4} \operatorname{sh} \beta_{\mathrm{k}} \mathrm{x}+ \\
& \frac{1}{2 \beta_{\mathrm{k}}^{2}}\left[\beta_{\mathrm{k}}\left(\mathrm{x}-\mathrm{x}_{\mathrm{i}}\right) \operatorname{ch} \beta_{\mathrm{k}}\left(\mathrm{x}-\mathrm{x}_{\mathrm{i}}\right)-\operatorname{sh} \beta_{\mathrm{k}}\left(\mathrm{x}-\mathrm{x}_{\mathrm{i}}\right)\right] \mathrm{H}\left(\mathrm{x}-\mathrm{x}_{\mathrm{i}}\right) \\
\Psi_{\mathrm{k}}^{\prime \prime}= & \mathrm{C}_{1}^{\prime \prime} \operatorname{ch} \beta_{\mathrm{k}} \mathrm{x}+\mathrm{C}_{2}^{\prime \prime} \operatorname{sh} \beta_{\mathrm{k}} \mathrm{x}+\mathrm{C}_{3}^{\prime \prime} \operatorname{ch} \beta_{\mathrm{k}} \mathrm{x}+\mathrm{C}_{4}^{\prime \prime} \operatorname{sh} \beta_{\mathrm{k}} \mathrm{x}+ \\
& \frac{1}{2 \beta_{\mathrm{k}}^{2}}\left[\beta_{\mathrm{k}}\left(\mathrm{x}-\mathrm{x}_{\mathrm{i}}\right) \operatorname{ch} \beta_{\mathrm{k}}\left(\mathrm{x}-\mathrm{x}_{\mathrm{i}}\right)-\operatorname{sh} \beta_{\mathrm{k}}\left(\mathrm{x}-\mathrm{x}_{\mathrm{i}}\right)\right] \mathrm{H}\left(\mathrm{x}-\mathrm{x}_{\mathrm{i}}\right)
\end{aligned}
$$

The derivatives of functions $\psi_{\mathrm{k}}$ have kinks and discontinuities, which correspond to the nature of the distribution of moments, longitudinal and shear forces in the direction perpendicular to the ribs.

Unknown $t_{k}$ and $m_{k}$ is determined from the conformance of the state of deformation at the contact line of the ribs. 


\section{Conclusions}

The presented method of calculating sandwich panels with a discrete filling in the form of ribs takes into account local disturbances of the stress field in the vicinity of the variable design properties. The calculation method based on the use of discontinuous generalized functions allows the determination of the state of stresses and deformations, stiffness and stability of multilayer plate structures. The function is discontinuous, where the derivatives of the function have kinks and discontinuities, which corresponds to the nature of the distribution of moments, longitudinal and compressive forces in the direction perpendicular to the ribs of the analyzed structure.

\section{References}

[1] Михайлов Б.К., Пластины и оболочки с разрывными параметрами, Л. ЛГУ, 1980.

[2] Гребень Е.С., Основные соотношения технической теории ребристых оболочек, Известия АНСССР. Механика 1965, 3, 81-92.

[3] Mikhailov B.K., Kipiani G.O., Strzemecka M., Stability of structural construktionunits in 3-sandvich plate with slots, Międzynarodowa Konferencja Naukowa. Najnowsze problemy budownictwa i inżynierii środowiska. Wydawnictwo Politechniki Białostockiej, Białystok 1989, I, 225-340.

[4] Rajczyk M., Kalinowski J., Analiza naprężeń ściany trójwarstwowej, Materiały międzynarodowej telekonferencji nt. Zwiększenie efektywności procesów przemysłowych i budowlanych, Częstochowa 2003.

[5] Михайлов Б.К., Кипиани Г.О., Москалева В.Г., Метод расчета трехслойной пластины с прямоугольны отверстием, Информационный листок 632-92, серия Р.30.19.53, Ленинградский центр научно-технической информации, 1992.

[6] Михайлов Б.К., Кипияни Г.О., Деформативность и устойчивость пространственных пластинчетых систем с разрывными параметрами. Стройиздат, Санкт-Петербур 1996.

[7] Райчык М. Факторы определяющие качество и свойства поверхности бетонных конструкции, Материалы международной научной конференции, Интерстроймех. СПбТУ, СПб. 2001, 312-318.

\section{Metoda obliczania płyt warstwowych z dyskretnymi połączeniami}

\section{STRESZCZENIE:}

W artykule przedstawiono metodę obliczeń wytrzymałościowych płyty warstwowej z użebrowaniem. Opracowana metoda obliczania płyt warstwowych z użebrowaniem uwzględnia lokalne zaburzenia pola naprężeń w sąsiedztwie różnych nieruchomości projektowych. Metoda obliczeniowa oparta na wykorzystaniu funkcji uogólnionych pozwala na określenie stanu naprężeń i odkształceń oraz sztywności i stateczności płyt wielowarstwowych.

\section{SŁOWA KLUCZOWE:}

płyta warstwowa; dyskretne połączenie; metoda obliczeniowa 